Keywords:

Tree plantation Productive capacity Artificial intelligence Site index

Historic: Received 28/04/2017 Accepted I |/08/20 17

Palavras chave: Plantios de árvores Capacidade produtiva Inteligência artificial Qualidade de sítio

\footnotetext{
${ }^{+}$Correspondence: dncosenza@gmail.com
}

DOI:
Diogo Nepomuceno Cosenzal+, Alvaro Augusto Vieira Soares², Aline Edwiges Mazon de Alcântara ${ }^{3}$, Antonilmar Araujo Lopes da Silva ${ }^{3}$, Rafael Rode ${ }^{4}$, Vicente Paulo Soares ${ }^{2}$, Helio Garcia Leite ${ }^{2}$

\section{SITE CLASSIFICATION FOR EUCALYPT STANDS USING ARTIFICIAL NEURAL NETWORK BASED ON ENVIRONMENTAL AND MANAGEMENT FEATURES}

ABSTRACT: Several methods have been proposed to perform site classification for timber production. However, there is frequent need to assess site productive capacity before forest establishment. This has motivated the application of Artificial Neural Networks (ANN) for site classification. Hereby, the traditional guide curve (GC) procedure was compared to the ANN with no stand measures as input. In addition, different ANN settings were tested to assess the best setting. The variables used to train the ANN were: climatic variables, soil types, spacing and genetic material. The results from the ANN and the GC methods were compared to the observed classes, which were defined using the observed dominant high at the age of seven years. The comparison was performed using the Kappa coefficient $(\mathrm{K})$ and descriptive analysis. The results showed that the cost function "Cross Entropy" and the output activation function "Softmax" were the best for this purpose. The ANN classification resulted in substantial agreement with the observed indices against a moderate agreement of the GC procedure. The change in growth patterns throughout the rotation may have hindered the proper classification by the CG method, which does not happen with the ANN. Moreover, the GC method shows efficiency on classification in cases which data from stands at the age close to the reference age are available. Also, it could be possible to improve its accuracy if another advanced regression techniques were applied. However, the ANN method presented here is not sensible to growth instability and allows classifying sites with no plantation history.

\section{CLASSIFICAÇÃO DE SÍTIO PARA POVOAMENTOS DE EUCALIPTO UTILIZANDO REDES NEURAIS ARTIFICIAIS BASEADA EM VARIÁVEIS AMBIENTAIS E DE MANEJO}

RESUMO: Vários métodos têm sido propostos para realizar a classificação de sítio para produção de madeira. No entanto, há necessidade frequente de se obter a capacidade produtiva do local antes mesmo do estabelecimento da floresta. Isto motivou a aplicação das Redes Neurais Artificiais (RNA) para classificação de sítio. Desta forma, o método tradicional da curva guia (CG) foi comparado com a RNA sem medidas do povoamento como variáveis preditivas. Além disso, diferentes configurações de RNA foram testadas. As variáveis utilizadas para treinamento da RNA foram: variáveis climáticas, tipos de solo, espaçamento e material genético. Os resultados obtidos pela RNA e CG foram comparados com as classes de referência, definidas utilizando altura dominantes de povoamentos observadas no sétimo ano de idade. A comparação foi realizada utilizando o coeficiente Kappa $(K)$ e análise descritiva. Os resultados mostraram que a função de custo "entropia cruzada" e a função de ativação da camada de saída "softmax" foram melhores para este propósito. A classificação pela RNA resultou em uma "concordância substancial" com a classificação observada, contra uma "concordância moderada" gerada pela CG. A mudança no padrão de crescimento das árvores durante o tempo dificultou a classificação pela CG. Entretanto, este método mostrou alta eficiência na classificação quando dados em idades próximas à de referência estão disponíveis. Além disso este método pode ser aprimorado se outras técnicas avançadas de regressão forem aplicadas. Porém o método da RNA apresentado aqui não é sensível à instabilidade do crescimento e permite classificar locais sem registro de plantios anteriores.

' Forest Research Centre, School of Agriculture, University of Lisbon - Lisbon, Portugal

2 Federal Rural University of the Amazon - Parauapebas, Pará, Brazil

${ }^{3}$ Celulose Nipo-Brasileira S.A, Belo Oriente, Minas Gerais, Brazil

${ }^{4}$ Federal University of West of Pará, Santarém, Pará, Brazil 


\section{INTRODUCTION}

The evaluation of the potential for timber production in forest sites is an age-old interest, accompanying the history of forest production and receives attention from the scientific community until nowadays (e.g. FERRAZ FILHO et al., 20I I ; PAULO et al., 20 I4; BONTEMPS; BOURIAUD, 2014; ADAMEC; DRÁPELA, 20 I6; MARCATTI et al. 2017; SCOLFORO et al., 2017).

These assessments may be based on the relationships between a few or several elements that influence the development of trees. Modeling these relationships is a way to integrate them, quantifying the site quality. For that, several models of different nature (statistical, mechanistic and computational intelligence) have been developed aiming at an accurate estimation of productivity level of forest lands.

As presented by Skovsgaard and Vanclay (2008), the methods for these site productivity assessments can be divided into two types: dendrocentric and geocentric. The first is based on information from the stand itself, usually one or a combination of several easily measured tree or stand variables. The second uses environmental data related to the site, such as precipitation, air temperature, physiography and pedology. Moreover, these methods can be used simultaneously to complement the evaluation, based on variables related directly or indirectly to site productivity.

In general, the dendrocentric assessment is the most widely used and site potential productive capacity is synthetized into what is known as "site index". This index is based on the concept of dominant and codominant height $\left(\mathrm{H}_{\text {dom }}\right)$, which is the average height of the 100 thickest trees per hectare at a given age (ASSMANN, 1970). However, this concept is based on the assumption that the trees present the same growth behavior over the years (WALTERS et al., 1989), which is not always observed in fast growing tree crops, frequently used in the tropical regions (ALDER, 1980).

The quantification of the site index is most commonly obtained through the guide curve (GC) procedure after fitting a linear or non-linear regression model in which mean dominant height is regressed against stand age. This is the most common procedure due to its simple application and given the vast available literature (e.g. BURKHART; TOMÉ, 20I2; CAMPOS; LEITE, 20I3). Besides site classification and area mapping, this index is frequently used in production prognosis such as in Clutter's model (CAMPOS; LEITE, 20I3).

On the other hand, when inventory data are not available, the productive potential can be assessed by geocentric methods. Lately, process-based models like CABALA (MIEHLE et al., 2009) and specially the 3-PG model have been more intensively applied in forestry (e.g. LANDSBERG, SANDS, 20I I; BORGES et al., 20I2). These types of models allow to access the site quality in the absence of inventory data or even before the establishment of tree plantations. As a result, they can be used as decision support tool for forest managers when planning the production or land management.

However, processed-based models involve quantified cause-effect relationships between the variables embedded in the sub-models and a thorough parameterization to generate accurate predictions. Because a general parameterization may not work in specific areas and because of the time and labor-consuming effort for new parameterizations, ecophysiological models may not be accessible for medium or small-sized companies and government agencies.

An alternative to the above-mentioned forest site classification methods is the use of technics based on Computational Intelligence $(\mathrm{Cl})$. This type of technique, especially the Artificial Neural Networks (ANN), has been applied in several studies in forestry (e.g. BINOTI et al., 20I3; CASTRO et al., 20I3; BINOTI et al., 20I5; DIAMANTOPOULOU et al., 20I5; REIS et al., 2016). This methods allows to extract information from a massive database consisting of continuous and categorical variables in order to recognize patterns between the input variables and a variable of interest.

The ANN can be seen as a parallel system composed of processing units (nodes), usually organized in layers, where a mathematical equation operates in order to transmit a signal across connections (axons) to another layer (BRAGA et al., 2007). Those axons are associated with weights which ponder the associations between a node and the layers. There are several types of neural networks, but the most used is the Multilayer Perceptron (MLP). The first layer is not computing and is represented by the input data. It will serve as an information source for subsequent layers. In this layer, each continous variable is represented by a single node, whereas for the categorical variables (converted into binary variable), each category is represented by a node.

Next, there is the middle layer (hidden layer), which will process the information through the activation functions of each node. These functions, usually nonlinear, normalizes the sum of the initial values, multiply them by their respective weights, and transmit that new sinapsis to the last layer. Finally, the last neuronal layer (output layer) processes the informations over again 
and produces the output, which can be quantitative (values) or qualitative (classes). The number of neurons in the final layer is equal to the number of variables to be estimated or the number of the classification categories (HAYKIN, 200I).

During training, the data presented are processed by the network with the initial parameters determined randomly and the estimative errors returned to the neural net to adjust their weights. A new cycle of training proceeds in an iterative process until the error is minimized according to a cost function .

One advantage of ANN is the possibility to use several continuous and/or categorical predictors (variables in the input layer), providing high precision estimates or classifications (e.g. GÖRGENS et al., 2009; AERTSEN et al., 20I0; LEITE et al., 20ll; SANQUETTA et al., 2017). This can be done without the problem of multicollinearity, regression assumptions or even without well-known processes (a priori) or cause-effect relationships involving these variables as in ecophysiological models, so that variable as dominant height could be replaced by another related one do predict site quality. Furthermore, in a previous study of $\mathrm{Cl}$ use for classification of production capacity, Cosenza et al. (2015) concluded that the ANN is able to perform this kind of task. However, in their work the training data was the classification generated by the guide curve, which hinders inference about the ANN efficiency over the usual GC method.

In this context, this study aimed at assessing the application of artificial neural networks to perform site classification for eucalypt stands based on environmental and silvicultural information to answer the following questions: what is the best network setting for site classification? Is the ANN method with no stand feature as input more accurate than the traditional GC method?

\section{MATERIAL AND METHODS}

The database used to perform the analysis is coming from a continuous forest inventory of 474 eucalypt stands located in Rio Doce valley in Minas Gerais states, Brazil. This region has national-wide importance concerning wood production for the pulp and charcoal market. These stands have, on average, $0.3 \mathrm{~km}^{2}$ of area and they are at a maximum distance of $270 \mathrm{~km}$ from each other, covering a considerable environmental variability.

We used the average dominant and co-dominant tree height at a referecence age as a proxy for site productive capacity. For that, the total tree height of the four thickest trees in $400-\mathrm{m}^{2}$ inventory plots was measured (ASSMANN, 1970), being one plot per stand. Each plot was measured once a year and all of them occur between the ages of two and ten years, with one of those measures taken at the age of seven years. This process generated a datasset with 2018 plot mean dominan heights. We chose the age of seven years as reference age, commonly used in short rotation of eucalypt stands in Brazil (CAMPOS; LEITE, 20I3).

In order to compare the results of the GC and ANN methods and assess their accuracy, a reference classification of the stands was established based on the observed dominant height at seven years old, which is the observed site index.Thus, each measure of a given stand received the same class determined in its reference age. With the range of site indexes, we established two classification types usually applied on area mapping: three and four classes, with amplitudes of $5.5 \mathrm{~m}$ and 4.0 $\mathrm{m}$, respectively (Table I).

TABLE I Site classifications based on the observed site index for short-rotation eucalypt stands. Class limits, mean dominant height and standard deviation (sd) are given in meters; $\mathrm{n}$ is the number of observations.

\begin{tabular}{cccccccccc}
\hline & \multicolumn{3}{c}{3 Classes } & \multicolumn{4}{c}{ 4 Classes } \\
\cline { 2 - 9 } Class & Class limits & $\mathrm{n}$ & $\begin{array}{c}\text { Mean } \\
(\mathrm{m})\end{array}$ & sd & Class limits & $\mathrm{n}$ & $\begin{array}{c}\text { Mean } \\
(\mathrm{m})\end{array}$ & sd \\
\hline A & $32-37.5$ & 458 & 29.29 & 5.50 & $33-37$ & 278 & 30.11 & 5.38 \\
B & $26.5-31.9$ & 1512 & 24.97 & 5.30 & $29-32.9$ & 1068 & 26.26 & 5.39 \\
C & $21-26.4$ & 138 & 20.27 & 4.96 & $25-28.9$ & 707 & 23.34 & 5.07 \\
D & - & - & - & - & $21-24.9$ & 55 & 19.13 & 4.83 \\
\hline
\end{tabular}

The site classes resulted from these two classifications were the output variables in the training of the ANN. As input variables we used: genetic material, spacing, rotation, soil type and climatic information. The levels of the variable "genetic material" may represent either a single genotype (stands planted with cuttings originated from vegetative propagation of a single genotype) or a species (stands planted with seedlings from sexual propagation).

A rotation is the period between the plantation (or coppice regeneration, no coppice data was present in our dataset) and the harvest. Therefore the variable "rotation" implies how many times the stand was grown, including the current stand. Soil type was defined based on the Brazilian Soil Classification System (EMBRAPA, 20I3) and was distinguished until the fourth category. As some stands presented more than one soil type, we used the two most abundant as two separate variables: "major" and "secondary" soil type. If a stand presented only one soil type in the records, this type was entered as both the major and the secondary soil type. The climatic information was collected from nine automatic agro- 
meteorological stations (Campbell model, CAMPBELL SCIENTIFIC INC., 20I7) distributed throughout the planted area. We used annual averages from the data collected between 2006 and 2013 (Table 2).

TABLE 2 Climatic variables used as inputs in the training of the artifitial neural networks.

\begin{tabular}{|c|c|c|c|c|}
\hline Variable & Unit & Minimum & Average & Maximum \\
\hline Annual Rainfall & $\mathrm{mm}$ & 994.8 & 1348.9 & I785.I \\
\hline $\begin{array}{l}\text { innual Rainfall standard } \\
\text { eviation }\end{array}$ & $\mathrm{mm}$ & 217.5 & 336.4 & 511.6 \\
\hline Aydric deficit & $\mathrm{mm}$ & 14.2 & 14.2 & 24.7 \\
\hline Maximum Temperature & ${ }^{\circ} \mathrm{C}$ & 21.0 & 23.9 & 29.7 \\
\hline Medium Temperature & ${ }^{\circ} \mathrm{C}$ & 16.0 & 19.3 & 22.8 \\
\hline Minimum Temperature & ${ }^{\circ} \mathrm{C}$ & 14.7 & 16.5 & 19.4 \\
\hline $\begin{array}{l}\text { Photosynthetically active } \\
\text { radiation }\end{array}$ & $\mathrm{mmol} \cdot \mathrm{m}^{-2}$ & 31231.1 & 33042.0 & 34998.9 \\
\hline Relative Humidity of air & $\%$ & 72.7 & 78.0 & 81.7 \\
\hline Total daily solar radiation & $\mathrm{MJ} \cdot \mathrm{m}^{-2} \cdot \mathrm{day}^{-1}$ & 12.8 & 14.5 & 17.4 \\
\hline Vapour Pressure Deficit & $\mathrm{hPa}$ & 4.1 & 5.8 & 8.4 \\
\hline Wind speed & $\mathrm{m} / \mathrm{s}$ & 1.3 & 3.1 & 4.3 \\
\hline
\end{tabular}

Since the study area is extensive for just nine weather stations, we decided to interpolate the information from the stations to the plots by using Thiessen polygons, with the aid of ArcGIS software, so that each stand received information from the nearest station. For the plots located in the border of two or more polygons, the arithmetic mean of the respective polygons was assigned. The reason for the use of this approach is its easy application and comprehension, and the fact that it allows interpolating all climatic variables simultaneously.

The data related to soil type, spacing, genetic material and rotation were obtained for each stand. There were in total 17 soil types, 49 genotypes and eight spacings, with distances betwee trees and rows varing from $2 \mathrm{~m}$ to $4 \mathrm{~m}$. We highlight that the focus of this study is not the effect of the variables itself, but the classification. Therefore, further characterization of the variables is not provided since it is beyond the scope of our objective.

For each classification type (three and four classes), 200 networks of the Multilayer Perceptron (MLP) type for classification were trained using the software Statistica 12 (STATSOFT INC., 2017) which uses the training algorithm Broyden-Fletcher-GoldfarbShanno (BFGS), an update of Quasi-Newton method (BISHOP, 1995). Multiple architectures were tested with respect to the number of neurons in the hidden layer, cost function and activation functions. The numbers of neurons in the hidden layer ranged from 15 to 30 units; the tested types of activation function of the hidden and output layer tested were the logistic function, identity, exponential, hyperbolic tangent and softmax; and the tested cost functions were the sum of squares and crossentropy (Table 3). At this stage, the data were divided in three parts, $70 \%$ of the data were used for training the ANN, $15 \%$ for testing and the other $15 \%$ for validation. We selected among the 200 trained networks the one that had the highest percentage of agreement between the estimated and the observed classification (hereafter called "hit"). If more than one ANN presented the same highest overall hit, we gave preference to that one with the least number of nodes in the hidden layer to avoid overfitting.

TABLE 3 Description of the activation and cost functions.

\begin{tabular}{|c|c|c|c|}
\hline \multicolumn{2}{|c|}{ Activation functions* } & \multicolumn{2}{|c|}{ Cost functions } \\
\hline Identity: & $\alpha$ & & \\
\hline Logistic: & $\frac{1}{1+e^{-\alpha}}$ & Cross Entropy: & $\mathrm{E}_{c e}=-\sum_{i=1}^{n} t_{i}^{*} \ln \left[\frac{y_{i}}{t_{i}}\right)$ \\
\hline Exponential: & $e^{-\alpha}$ & & \\
\hline Hyperbolic tangent: & $\frac{e^{\alpha}-e^{-\alpha}}{e^{\alpha}+e^{-\alpha}}$ & Sum of Squares: & $\mathrm{E}_{s o s}=\sum_{i=1}^{n}\left(y_{i}-t_{i}\right)^{2}$ \\
\hline Softmax: & $\frac{e^{\left(\alpha_{j}\right)}}{\sum_{j=1}^{k} e^{\left(\alpha_{j}\right)}}$ & & \\
\hline
\end{tabular}

* $a$ is the signal received by the a node; $a j$ is the signal received by the node $j$ in the output layer; and $k$ is the total number of neurons in the output layer; $n$ is the number of training data; $y i$ is an estimate of the observed value $t ;$;

The training data is used to adjust the network weights. Because of that, setting a large percentage of data as the trainning data is recommended so that it covers the range of variability of all variables and their categories. Through the testing data, new classification errors are obtained for each iteration, but it is not directly related to the weights adjustment. As presented by Haykin (200I), this error tend to decrease at the beginning of trainning and to grow as the network becomes more specific to the trainning data. Based on this fact, the software stops the iterations before the test error starts to grow, avoiding the occurrence of overfitting (STATSOFT INC., 2017).

The validation data is used to calculate the network generalization error after the training is complete. This parameter serves as another way to assess the network quality (STATSOFT INC., 2017). Even though these two data partitions (test and validation) comprise a smaller part of the dataset (30\%), they still cover a substantial volume of occurrences.

Once selected, the best ANN (one for each classification type) were applied to the entire database to asses their classification accuracy. To evaluate the effect of the data partition percentage on the training, the configuration of the two selected networks was used to build new ANN with diferent training 
partition. With the selected configurations, 20 new ANN were trained using ten percentages of trainning data from $100 \%$, with $10 \%$ reduction, down to $10 \%$. Consequently, the remaining fraction of data used for testing was $0 \%, 10 \%$, up to $90 \%$, with no partitioning for validation. These different data partitionings for training were compared by their average hits (average estimated classification matching the observed data in 20 repetitions for each percentage level of training data) for each class.

The ANN method was compared with the site classification via the guide curve method. The Schumacher's equation was used to relate dominant height $\left(\mathrm{H}_{\text {dom }}\right.$, in meters) to age ( $\mathrm{t}$, in months). The parameters $\alpha$ and $\beta$ were estimated via LevenbergMarquardt algorithm and goodness-of-fit was analyzed through the statistics bias and root mean squared error (RMSE), calculated as Campos and Leite (2013), and through the residuals analysis plots.

The results of each classification approach (neural network and guide curve) were compared through the Kappa analysis (COHEN, 1960; CONGALTON; MEAD, 1983) which gives a measure of classification agreement (Table 4 ).

TABLE 4 Classification level of Kappa coefficient (LANDIS; $\mathrm{KOCH}$, 1987).

\begin{tabular}{cc}
\hline Kappa coefficient & Strength of Agreement \\
\hline$<0.00$ & Poor \\
$0.00-0.20$ & Slight \\
$0.2 \mid-0.40$ & Fair \\
$0.4 \mid-0.60$ & Moderate \\
$0.6 \mid-0.80$ & Substantial \\
$0.8 \mid-1.00$ & Almost Perfect \\
\hline
\end{tabular}

The comparison between two Kappa coefficients (equation I) was performed through the $\mathrm{Z}$ test (equation 2 ) to verify the alternative hypotesis $\mathrm{H}_{1}: \mathrm{K}_{1} \neq \mathrm{K}_{2}$, with $5 \%$ significance, in each classification type (three and four classes). Those coefficients were computed from the error matrices of each classification method through the set of equations described by Hudson and Ramm ( 1987) as follows [I], [2],[3], [4] where $k=$ Kapa coefficient estimative; $\sigma^{2}[\mathrm{~K}]=$ variances estimated for the Kappa estimatives, being $\hat{\sigma}_{1}^{2}$ and $\hat{\sigma}_{2}^{2}$ the variance for $k_{1}$ and $R_{2}$ respectively; $N=$ total number of observations; $r=$ number of classes; $X_{i i}=$ number of correct classifications; $X_{i+}=$ marginal total of row $\mathrm{i} ; X_{+i}=$ marginal total of column $i ; X_{i j}=$ observations on row $i$ and column $j ; X_{j+}=$ marginal total of column $j$.

$\hat{\mathrm{K}}=\frac{\theta_{1}-\theta_{2}}{1-\theta_{2}} ; \frac{\hat{\mathrm{K}}_{1}-\hat{\mathrm{K}}_{2}}{\sqrt{\hat{\sigma}_{1}^{2}+\hat{\sigma}_{2}^{2}}} \sim \mathrm{Z}$

$$
\begin{aligned}
& \hat{\sigma}^{2}[\hat{\mathrm{K}}]=\frac{1}{\mathrm{~N}} \cdot\left[\frac{\theta_{1}\left(1-\theta_{1}\right)}{\left(1-\theta_{2}\right)^{2}}+\frac{2\left(1-\theta_{1}\right)\left(2 \theta_{1} \theta_{2}-\theta_{3}\right)}{\left(1-\theta_{2}\right)^{3}}+\frac{\left(1-\theta_{1}\right)^{2}\left(\theta_{4}-4 \theta_{2}\right)}{\left(1-\theta_{2}\right)^{4}}\right] \\
& \theta_{1}=\sum_{\mathrm{i}=1}^{\mathrm{r}} \frac{\mathrm{X}_{\mathrm{ii}}}{\mathrm{N}}, \theta_{2}=\sum_{\mathrm{i}=1}^{\mathrm{r}} \frac{\left(\mathrm{X}_{\mathrm{x}+} \cdot \mathrm{X}_{+\mathrm{i}}\right)}{\mathrm{N}^{2}} \\
& \theta_{3}=\sum_{\mathrm{i}=1}^{\mathrm{r}} \frac{\mathrm{X}_{\mathrm{ii}}\left(\mathrm{X}_{\mathrm{i}+}+\mathrm{X}_{+\mathrm{i}}\right)}{\mathrm{N}^{2}}, \theta_{4}=\sum_{\substack{i=1 \\
j=1}}^{\mathrm{r}} \frac{\mathrm{X}_{\mathrm{ij}}\left(\mathrm{X}_{\mathrm{j}+}+\mathrm{X}_{+\mathrm{i}}\right)^{2}}{\mathrm{~N}^{3}}
\end{aligned}
$$

\section{RESULTS}

The classification based on the observed site index shows that as the stand age distances from the reference age, plots of a given class may change to another class. In our data, this happened especially for periods of time before the reference age, and the further they are from the reference age, more variable the classification becomes. This is depicted in Figure Ia and Ib, where the mean dominant heights of all measurements were plotted together with the observed site index (at age seven years old).

The summary of the selected networks is presented in Table 5. In accordance with the result found by Cosenza et al. (20I5), for both the selected networks, the cost function was the "Cross Entropy" and the activation function was the softmax (both of these functions are discribed in Bishop (1995), which makes its use advisable for this type of task.

With these configurations, the neural networks presents probabilistic properties which assumes a multinomial distribution of classes (STATSOFT INC., 2017). Each one of the output neuron presents a value equivalent to the probability of being selected as the best classifier for a certain stand, to which the class of the highest value neuron will be assigned. The ANN site classification for each stand measurement is shown in Figures Ic and Id.

The classification through the guide curve method is shown in Figure le and If. The adjusted equation presented good accuracy (bias $=0.013$; RMSE $=9.23 \%$ ) and well distributed residuals (Figure 2).

The absolute value for each class obtained by the ANN method was closer to the number of cases in each reference class than the GC method (Table 6), for both classification types (three and four classes). However, this value itself does not distinguish the misclassifications, so that this parameter cannot be considered without an analysis of the percentage of errors and the Kappa coefficients. According to these parameters, the ANN can be considered more accurate than the GC method, especially in the threeclass division, presenting a substantial agreement (Table 4) with the reference class, while GC has a moderate accuracy. There was greater percentage of error in the extremity classes in the three-class division, indicating smaller sensitivity of the methods to distinguish them. 
TABLE 5 Artificial neural networks configuration for site classification of Eucalyptus stands in southeastern Brazil.

\begin{tabular}{|c|c|c|c|c|c|c|c|}
\hline \multirow{2}{*}{ Classification type } & \multirow{2}{*}{ Architecture* } & \multicolumn{3}{|c|}{ Overall classification result (\%) } & \multirow{2}{*}{ Cost Function } & \multicolumn{2}{|c|}{ Activation function } \\
\hline & & Training & Test & Validation & & Hidden layer & Output payer \\
\hline 3 Classes & MLP I03-19-3 & 91.53 & 90.19 & 89.87 & Cross entropy & Logistic & Softmax \\
\hline 4 Classes & MLP I03-30-4 & 85.98 & 82.91 & 83.86 & Cross entropy & Tang. Hyperbolic & Softmax \\
\hline
\end{tabular}

*Distribution of neurons in the input, hidden and output layer respectively.
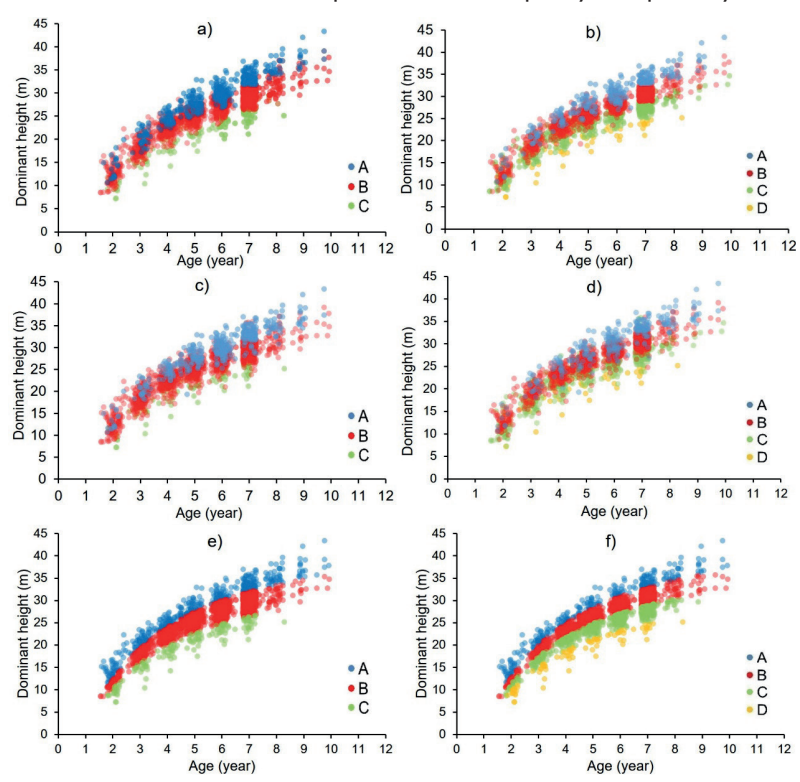

FIGURE I Site classification for short rotation eucalypt stands in the state of Minas Gerais, southeastern Brazil. Classification based on the observed site index with three (a) and four (b) classes, ANN classification with three (c) and four (d) classes and GC classification with three (e) and four classes (f).

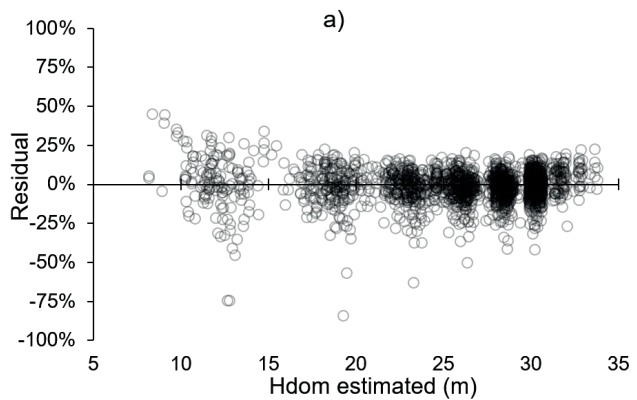

b)

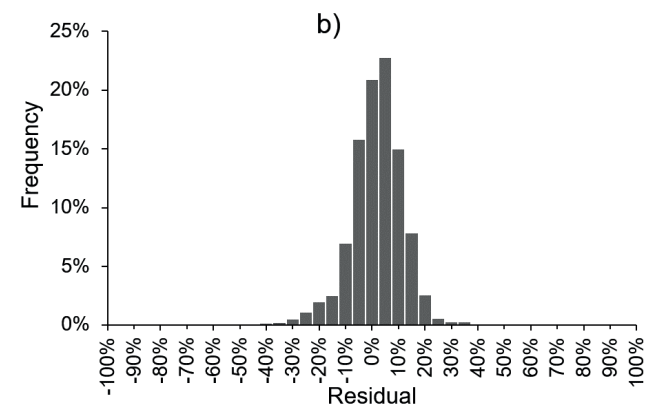

FIGURE 2 Residual dispersion (a) and frequency histogram (b) for the model fitted for the guide-curve site classification procedure in Eucalyptus stands in southeastern Brazil.
Regarding the test of different percentage of data during the training phase, in both cases (three and four classes), the percentage of hits was lower for the extremity classes in all levels of training (Figure 3). In addition, the accuracy level increased with the size of the training data and the precision became stable from the $60 \%$ level onwards.

Considering the total hits, both of the classifications estabilized around the level of $60 \%$. However, the increase in percentage of hits was steeper when four classes were established.

In order to evaluate the potential of the two methods of classification in the reference age, the database was filtered, selecting the measures occurring between the 81 th and 87 th months, which represents the reference age (84th month) with three months tolerance. This selection corresponded to 474 observations, and the results are presented in Table 7.

Different from what was observed with the full data classification (plots throughout age), the guide curve was more accurate than the neural networks, drastically reducing the misclassifications and increasing the Kappa coefficient to an almost perfect level of agreement with the reference data. On the other hand, the ANN had errors with similar proportions as for the entire data tested previously and the same Kappa coefficients.

Another difference observed between the two methods is the variation of stand class throughout the years when the guide curve was applied, mainly at ages distant from the reference age. This fact is discussed by Walters et al. (1989) as a technical limitation of the guide curve, which assumes that the site index of a given stand will be the same for all ages. According to these authors, this premise may be inconsistent since in the case of an average site index, changing this average could cause biased curves.

That situation is exemplified in Figure 4 for a single stand in the three-class division. The stand changed its class three times throughout the years, which could be better observed through the position of site index line (black dotted line) on the colored box. At the third year, this stand was classified as Class $A$ and jumps to the Class B. In the next year, it is classified as Class $C$ and then it goes back to Class $B$, becoming quite close to the dominant height. This explains the lower classification accuracy of this technique when applied in the full 
TABLE 6 Agreement of the site classification based on the observed site index (reference) and classified using artificial neural networks (ANN) and the guide-curve procedure (GC).

\begin{tabular}{|c|c|c|c|c|c|c|c|c|c|c|}
\hline \multirow[b]{2}{*}{ Class } & \multicolumn{5}{|c|}{3 classes } & & \multicolumn{4}{|c|}{4 classes } \\
\hline & Reference & ANN & $\begin{array}{c}\text { ANN error } \\
(\%)\end{array}$ & GC & GC error & Reference & ANN & ANN error & GC & $\begin{array}{c}\text { GC error } \\
(\%)\end{array}$ \\
\hline$A$ & 458 & 427 & 18 & 527 & $29 \%$ & 278 & 304 & $14 \%$ & 336 & 32 \\
\hline B & 1512 & 1574 & 4 & 1423 & $17 \%$ & 1068 & $\mathrm{I}, 045$ & $14 \%$ & IIOI & 24 \\
\hline $\mathrm{C}$ & 138 & 107 & 30 & 158 & $30 \%$ & 707 & 722 & $15 \%$ & 588 & 37 \\
\hline$D$ & - & - & - & - & - & 55 & 37 & $33 \%$ & 83 & 25 \\
\hline Overall & 2108 & 2108 & 10 & 2108 & $21 \%$ & 2108 & 2,108 & $15 \%$ & 2108 & 30 \\
\hline Kappa* & & $0.79^{a}$ & & $0.55^{b}$ & - & - & $0.72^{\mathrm{a}}$ & - & $0.52^{b}$ & - \\
\hline
\end{tabular}

*Coefficients superscriped by same letters for each class division do not differ.
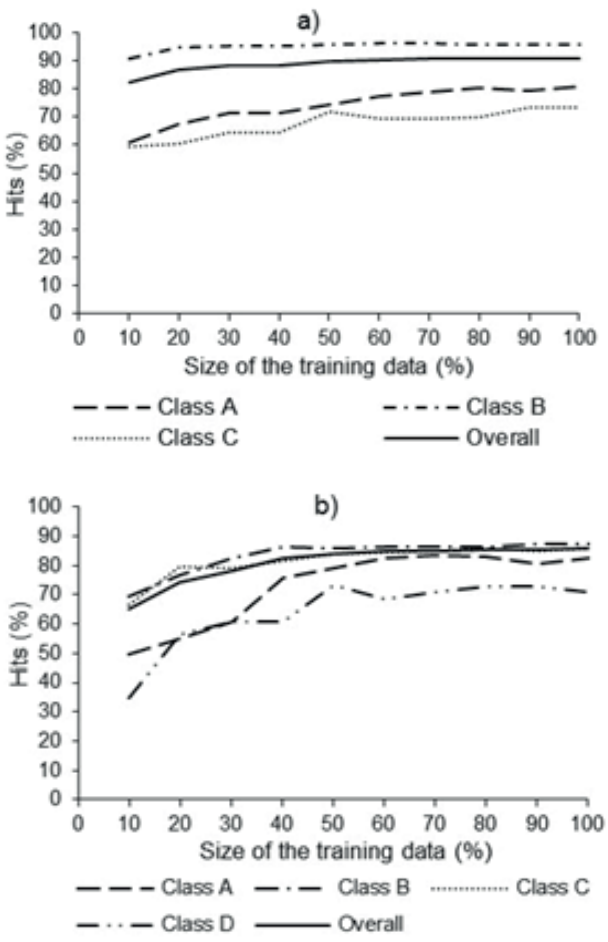

FIGURE 3 Accuracy graphs for different percentages of network training data for the classification based in three (a) and four (b) classes.

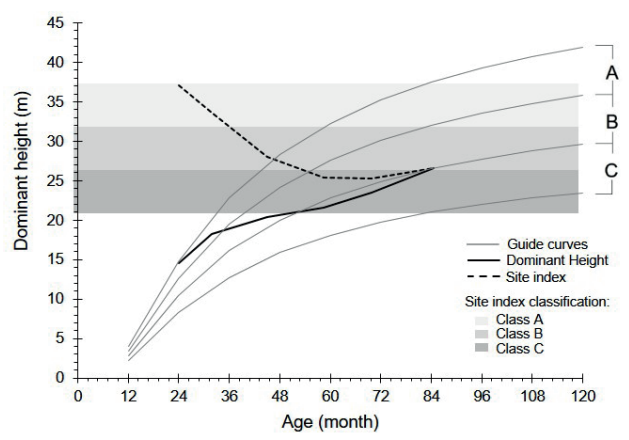

FIGURE 4 Observed mean dominant height (black full line), site index estimated by the guide-curve (black dotted line), dominant height class limits for the guide-curve (gray lines) and site classes based on the observed calculated site index (colored stripes). database in comparison with the data in the reference age. That misclassification may not occur because of the chosen model itself, but due to the instability of the dominant height growth throughout rotation or even data collection mistakes, which would probably result in a certain degree of accuracy error if any growth-theory based technique was applied to model the relationship between age and dominant height.

For both divisions, three and four classes, there were respectively 225 (47\%) and I 30 (27\%) reclassified stands. This did not occur with the ANN because the variables used as input training did not vary within the sites, only among them. In the case of the stand presented on Figure 4, all measurements were correctly classified as Class B by the ANN.

\section{DISCUSSION}

The overlap of reference classes of some stands (Figure $\mathrm{Ia}$ and $\mathrm{Ib}$ ) occurs due to the change in the growth rate over the years for the different measured plots, which influences the average dominant height of the plots and/or the stands. Therefore, this fact has contributed to increasing the misclassification with the guide curve in early or old ages.

The precise explanation for the changes in average dominant height and the growth rate for the studied stands goes beyond to the objectives of this work. There are several factors that influence tree development that might have caused it, such as edaphic and climatic factors, occurrence of pests and diseases, genetic issues and cultural treatments (e.g. ALMEIDA et al., 2007; BINKLEY et al., 20I0; FORRESTER et al., 20I0; STAPE et al., 20I0; BARTHOLOMÉ et al., 20I3). Furthermore, Alder (1980) brings out that, in tropical regions, uniform stands of fast-growing species can have variations in the growth rate, so that the dominant height may cease to be a good indicator of productivity. However, our study suggests that the choice of the reference age for this evaluation methodology is very important in the definition 
TABLE 7 Site classification at the reference age of seven years based on the observed site index (Reference) and classified using artifitial neural networks (ANN) and the guide-curve procedure (GC).

\begin{tabular}{|c|c|c|c|c|c|c|c|c|c|c|}
\hline \multirow{2}{*}{ Class } & \multicolumn{5}{|c|}{3 classes } & \multicolumn{4}{|c|}{4 classes } & \multirow[b]{2}{*}{ GC erro } \\
\hline & Real & ANN & ANN error & GC & GC error & Real & ANN & ANN error & GC & \\
\hline $\mathrm{A}$ & 118 & 115 & $15 \%$ & 116 & $5 \%$ & 74 & 79 & $14 \%$ & 74 & $4 \%$ \\
\hline B & 330 & 339 & $5 \%$ & 331 & $2 \%$ & 242 & 235 & $14 \%$ & 245 & $4 \%$ \\
\hline C & 26 & 20 & $31 \%$ & 27 & $8 \%$ & $\begin{array}{c}148 \\
10\end{array}$ & $\begin{array}{c}153 \\
7\end{array}$ & $\begin{array}{l}14 \% \\
30 \%\end{array}$ & $\begin{array}{c}145 \\
10\end{array}$ & $\begin{array}{l}7 \% \\
0 \%\end{array}$ \\
\hline $\begin{array}{l}\text { Overall } \\
\text { Kappa* }\end{array}$ & 474 & $\begin{array}{c}474 \\
0.79^{\mathrm{a}} \\
\end{array}$ & $9 \%$ & $\begin{array}{c}474 \\
0.93^{\mathrm{b}}\end{array}$ & $3 \%$ & 474 & $\begin{array}{c}474 \\
0.77^{\mathrm{a}} \\
\end{array}$ & $15 \%$ & $\begin{array}{c}474 \\
0.92^{\mathrm{b}}\end{array}$ & $5 \%$ \\
\hline
\end{tabular}

*Coefficients superscriped by same letters for each class division do not differ.

of site classes, being more susceptible to misclassification as more distant is the time between the reference year and the stand age.

The classification made by the neural network also generated overlaps, possibly due to the nature of the training data. Nonetheless, the system could classify the areas with relatively low errors, of $10 \%$ and $15 \%$ for the division of three and four classes respectively, and with a substantial agreement. Therefore, the ANN method was more precise than the guide curve and with no class changing between measurements of a same stand, since the categorical variables used for prediction do not changes over time and the climatic variables were the annual averages over eight years.

It must be highlighted that after training the ANN no tree measures were used to apply it, only environmental and silvicultural information. This advantage allows regions to be mapped according to their environmental features and even to simulate management options to be adopted and modifying them to boost productivity.

However, when it comes to classifying stands with measures near the reference age, the guide curve method was more precise, presenting 3\% and $5 \%$ of misclassification and an almost perfect agreement with the reference data, whereas the ANN showed the same error pattern and Kappa coefficients. Therefore, if measurements near the reference age are available, preference should be given to the guide curve method rather than using ANN with only environmental and silvicultural information.

Both the ANN and the guide curve can be potentially improved by including other variables in the models. For example, regarding the ANN, Blackard and Dean (1999) included several physiographic variables to predict seven forest cover types in the Roosevelt National Forest (Colorado, USA) and reached $70.58 \%$ of accuracy. Among the used variables, there was the elevation, aspect (azimuth from the true north), slope and distance from water bodies, and of known fire ignition points. Also, Hilbert and Van Den Muyzenberg (1999) included climatic and physiographic variables to classify I 5 forest types in a tropical rainforest in Australia which resulted in an ANN overall accuracy of $75 \%$ and Kappa coefficient of 0.676 . An interesting variable used by them was the soil water index (SWI), calculated from the digital terrain model (DTM), which is related to the soil wetness. In summary, each one of those features were related in some way to the forest production and probably would influence site quality, so that they could be included in the networks training.

On the other hand, adding environmental and silvicultural covariates in regression model could also improve the guide curve method. For example, Scolforo et al. (2013) used exploratory data analysis to select climatic variables and use it as input on Chapman and Richards model so that it increased its precision in $33 \%$. Like the ANN, this kind of modified models can be potentially used to simulate site capacity with no planting history or in case of climatic changes. It is also important to emphasize that, in our work, no distinction among genotypes and plots was made during the fitting process, so that the $\mathrm{H}_{\text {dom }}$-curve was fitted using the full dataset. Thus, advanced regression techniques such as mixed models could be applied to improve site index estimation, since they can embody these factors and can correct for residual serial autocorrelation caused by using longitudinal data of permanent plots (e.g. CALEGARIO et al., 2005). An advantage of this methods is the possibility to draw statistical inferences regarding the regression parameters, which cannot be made for ANN. Furthermore, even though the guide curve is widely used, the permanent plot could violate the residual independence assumption, so that other approach as algebraic differential models could be applied to build the site index curves (BURKHART; TOMÉ, 2012; CAMPOS; LEITE, 20I3).

Also, we believe that more weather stations associated to other interpolation technics, such as Kriging or the Inverse Distance Weighted (IDW), could improve the prediction performance of the ANN by incorporating climatic variations on the terrain in a smaller scale.

Regarding the proportion of training data we found that, from $60 \%$ on, there is little variation on the estimates accuracy, since the remaining data is used as 
test. As presented by Jain et al. (1996), the number of training patterns is determined by the sample complexity. In this way, this result implies that the variability in the training data, which allows the ANN to learn, is more important than the amount of data itself.

If a reduced training data is used, the range of variability can be unrepresentative and could be a great risk of a given characteristic not to be detected by the network (underfitting), reducing the network generalization capacity for situations not displayed during the training phase. On the other hand, greater percentages of training data, besides not improving the quality of the training process, may increase the processing time.

Therefore, we highlight that the optimum training data obtained in this research will not necessarily be the same in other datasets. A test must be performed for each database because the training proportion probably will be bigger in situations of higher variability and smaller in less variable datasets.

This work reinforces the potential of the artificial neural networks to be applied to forest modeling. The classification of the productive potential based on environmental and management variables was shown to be a good technique for site mapping and, therefore, can be used as a support tool for forest managers, when deciding about management prescriptions or land management.

In addition, we encourage more research to assess the sensitivity of the variables used in networks so that the less influential variables on prediction may be excluded. Reducing the quantity of predictors will potentially reduce the computational cost of training and facilitate their application, especially in situations where some variables may not be available or difficult to be obtained. Additional studies are warranted to improve the use of the technique to make it more precise and more practical, including with application to other locations and forestry species. We emphasize that, like all decision support tools, its results must undergo the scrutiny of the manager and other agents involved in the production process to minimize the occurrence of mistakes.

\section{CONCLUSION}

The best artificial neural network (ANN) setting comprised a number of hidden units equal to a fifth of input neurons in a Multilayer Perceptron neural network (MLP) with the cross entropy cost function and the logistic and Softmax activation functions in the hidden and output layer, respectively. Decreasing the amount data used for training down to $60 \%$ did not result in considerable change in classification accuracy.
For both Guide Curve (GC) and ANN procedure, using three site classes results in more accurate classification then using four site classes. In general, the ANN using only environmental and silvicultural inputs provides better classification accuracy than the GC method, which allows that methodology to be applied in absence of dominant height data or stand history provided there is an ANN previously trained for it. However, in the case of established stands with age near the reference year, the GC should be prioritized for site classification, given its better precision. ANN provides better classification accuracy than traditional GC method when plantations with age far from the reference age.

\section{ACKNOWLEDGEMENTS}

We thank the Brazilian National Council of Scientific and Technological Development (CNPq) for supporting this project.

The Forest Research Centre, School of Agronomy, University of Lisbon is a research unit funded by Fundação para a Ciência e a Tecnologia I.P. (FCT), Portugal (UID/ AGR/00239/2013).

\section{REFERENCES}

ADAMEC, Z.; DRÁPELA, K. Comparison of parametric and nonparametric methods for modeling height-diameter relationships. iForest - Biogeosciences and Forestry, v. 9, p. el-e8, 2016.

AERTSEN, W.; KINT, V.; VAN ORSHOVEN, J.; ÖZKAN, K.; MUYS, B. Comparison and ranking of different modelling techniques for prediction of site index in Mediterranean mountain forests. Ecological modelling. v. 221, n. 8, p. III9-II30, 2010.

ALDER, D. Forest volume estimation and yield prediction rediction: vol. $\mathbf{2}$ - yeld prediction. Rome: FAO Forestry Paper, 1980. 194p.

ALMEIDA, A. C.; SOARES, J. V.; LANDSBERG, J.J.; REZENDE, G. D. Growth and water balance of Eucalyptus grandis hybrid plantations in Brazil during a rotation for pulp production. Forest Ecology and Management, v. 25I, n. I-2, p. I0-2I, 2007

ASSMANN, E. The principles of forest yield study: studies in the organic production, structure, increment and yield of forest stands. Pergamon Press, 1970, 520p.

BARTHOLOMÉ, J.; SALMON, F; VIGNERON, P.; BOUVET, J.; PLOMION, C.; GION, J. Plasticity of primary and secondary growth dynamics in Eucalyptus hybrids: a quantitative genetics and QTL mapping perspective. BMC Plant Biology, v. I3, p. I20, 2013. 
BINKLEY, D.; STAPE, J. L.; BAUERLE, W. L.; RYAN, M. G. Explaining growth of individual trees: Light interception and efficiency of light use by Eucalyptus at four sites in Brazil. Forest Ecology and Management, v. 259, n. 9, p. |704-|7|3, 2010.

BINOTI, D. H. B.; BINOTI, M. L. M. da S.; LEITE, H. G.; SILVA, A. A. L. da; ALBUQUERQUE, A. C. Modelagem da distribuição de diametros utilizando autômatos celulares e redes neurais artificiais. CERNE, v. 19, n. 4, p. 677-685, 2013.

BINOTI, M. L. M. D. S.; LEITE, H. G.; BINOTI, D. H. B.; GLERIANI, J. M. Stand-level prognosis of eucalyptus clones using artificial neural networks. CERNE, v. 21, n. I, p. 97-105, 2015.

BISHOP, C. M. Neural networks for pattern recognition. Oxford, U.K.: Oxford University Press, 1995. 482p.

BLACKARD, J. A.; DEAN, D. J. Comparative accuracies of artificial neural networks and discriminant analysis in predicting forest cover types from cartographic variables. Computers and Electronics in Agriculture, v. 24, n. 3, p. |3|-|5|, 1999.

BONTEMPS, J. D.; BOURIAUD, O. Predictive approaches to forest site productivity: Recent trends, challenges and future perspectives. Forestry, v. 87, n. I, p. 109 $128,2014$.

BORGES, J. S.; NEVES, J. C. L.; LOURENÇO, H. M.; BARROS, N. F; DIAS, S. C. M. Parameterization of the 3-PG model for eucalypt in the region of Cerrado in Minas Gerais State. Ciência Florestal, v. 22, n. 3, p. 567-578, 2012.

BURKHART, H. E.; TOMÉ, M. Modeling forest trees and stands. Dordrecht: Springer, 20I2. 457p.

BRAGA, A. P.; CARVALHO, A. P. L. F.; LUDEMIR, T. B. Redes neurais e aplicações. $2^{a}$ ed. Rio de Janeiro, Brazil: LTC editora, 2007. 238p.

CALEGARIO, N.; DANIELS, R. F; MAESTRI, R.; NEIVA, R. Modeling dominant height growth based on nonlinear mixedeffects model: A clonal Eucalyptus plantation case study. Forest Ecology and Management, v. 204, n. I, p. I I-20, 2005.

Campbell Scientific. Available at: <http://www.campbellsci. com/>. Accessed in april 28, 2017.

CAMPOS, J. C., LEITE, H. G. Mensuração Florestal: perguntas e respostas. $4^{\mathrm{a}}$ ed. Viçosa, Brazil: Editora UFV, $2013.605 p$.

CASTRO, R. V. O.; SOARES, C. B. P.; LEITE, H. G.; SOUZA, A. L. de; NOGUEIRA, G. S.; MARTINS, F. B. Individual growth model for eucalyptus stands in Brazil using artificial neural network. ISRN Forestry, v. 2013, p. I-12, 2013.

COHEN, J. A coefficient of agreement for nominal scales. Educational and Psychological Measurement, v. 20, n. I, p. 37-46, 1960.
CONGALTON, R. G.; MEAD, R. A. A quantitative method to test for consistency and correctness in photointerpretation. Photogrammetric Engineering \& Remote Sensing, v. 49, n. I, p. 69-74, 1983.

COSENZA, D. N.; LEITE, H. G.; MARCATTI, G. E.; BINOTI, D. H. B.; ALCÂNTARA, A. E. M. de; RODE, R. Site classification with support vector machine and artificial neural network. Scientia Forestalis, v. 43, n. 108, p. 955-963, 2015.

DIAMANTOPOULOU, M. J.; ÖZÇELIK, R.; CRECENTECAMPO, F; ELER, Ü. Estimation of Weibull function parameters for modelling tree diameter distribution using least squares and artificial neural networks methods. Biosystems Engineering, v. 133, p. 33-45, 2015.

EMBRAPA (BRAZILIAN AGRICULTURAL RESEARCH CORPORATION). Brazilian System of Soil Classification (Sistema Brasileiro de Classificação de Solos). 3. ed. Brasília, DF, Brazil: Embrapa. 2013. 353p.

FERRAZ FILHO, A. C.; SCOLFORO, J. R. S.; FERREIRA, M. Z.; MAESTRI, R.; ASSIS, A. L. de; OLIVEIRA, A. D. de; MELLO, J. M. de. Dominant height projection model with the inclusion of environmental variables. CERNE, v. I7, n. 3 , p. $427-433,201$ I.

FORRESTER, D. I.; MEDHURST, J. L.; WOOD, M.; BEADLE, C. L.; VALENCIA, J. C. Growth and physiological responses to silviculture for producing solid-wood products from Eucalyptus plantations: An Australian perspective. Forest Ecology and Management, v. 259, n. 9, p. 1819-1835, 2010.

GÖRGENS, E. B.; LEITE, H. G.; SANTOS, H.do N.; GLERIANI, J. $M$. Estimação do volume de árvores utilizando redes neurais artificiais. Revista Árvore, v. 33, n. 6, p. I|4|-I |47, 2009.

HAYKIN, S. Neural Networks: a comprehensive fundation. $2^{\mathrm{a}}$. ed. Prentice Hall International, Inc., 200 I. 842p.

HILBERT, D. W.; VAN DEN MUYZENBERG, J. Using an artificial neural network to characterize the relative suitability of environments for forest types in a complex tropical vegetation mosaic. Diversity and Distributions, v. 5, n. 6, p. 263-274, Nov. 1999.

HUDSON, W. D.; RAMM, C. W. Correct formulation of the kappacoefficient of agreement. Photogrammetric engineering and remote sensing, v. 53, n. 4, p. 42I-422, 1987.

JAIN, A K.; MAO, J. C.; MOHIUDDIN, K. M. Artificial neural networks: A tutorial. Computer, v. 29, n. 3. p. 3 I-44, 1996.

LANDIS, J. R.; KOCH, G. G. The measurement of observer agreement for categorical data. Biometrics, v. 33, n. I, p. I59-174, 1987.

LANDSBERG, J. J.; SANDS, P. Physiological ecology of forest production: principles, processes and models. v. 4. $I^{\mathrm{a}}$ ed. Amsterdam: Elsevier, 20 I I. 352p. 
LEITE, H. G., SILVA, M.L.M., BINOTI, D.H. B., FARDIN, L.; TAKIZAWA, F. H. Estimation of inside-bark diameter and heartwood diameter for Tectona grandis Linn. trees using artificial neural networks. European Journal of Forest Research, v. 130, n. 2, p. 263-269, Mar. 2011.

MARCATTI, G. E.; RESENDE, R. T.; RESENDE, M. D. V; RIBEIRO, C. A. A. S.; DOS SANTOS, A. R.; DA CRUZ, J. P.; LEITE, H. G. GIS-based approach applied to optimizing recommendations of Eucalyptus genotypes. Forest Ecology and Management, v. 392, p. I44-I53, 2017.

MIEHLE, P.; BATTAGLIA, M.; SANDS, P. J.; FORRESTER, D. I.; FEIKEMA, P. M.; LIVESLEY, S. J.; MORRIS, J. D.; ARNDT, S. K. A comparison of four process-based models and a statistical regression model to predict growth of Eucalyptus globulus plantations. Ecological Modelling, v. 220, n. 5, p. 734-746, 2009.

PAULO, J. A.; PALMA, J. H. N.; GOMES, A. A.; FARIAS, S. P.; TOMÉ, J.; TOMÉ, M. Predicting site index from climate and soil variables for cork oak (Quercus suber $L$.) stands in Portugal. New Forests, v. 46, n. 2, p. 293-307, 2014.

REIS, L. P.; de SOUZA, A. L.; MAZZEI, L.; dos REIS, P. C. M.; LEITE, H. G.; SOARES, C. P. B.; TORRES, C. M. M. E.; da SILVA, L. F.; RUSCHEL, A. R. Prognosis on the diameter of individual trees on the eastern region of the amazon using artificial neural networks. Forest Ecology and Management, v. 382, p. I6I-167, 2016.
SANQUETTA, C. R.; PIVA, L. R.; WOJCIECHOWSKI, J.; CORTE, A. P.; SCHIKOWSKI, A. B. Volume estimation of Cryptomeria japonica logs in southern Brazil using artificial intelligence models. Southern Forests, v. 2620, p. I-8, 2017

SCOLFORO, J. R. S.; MAESTRI, R.; FERRAZ FILHO, A. C.; de MELLO, J. M.; de OLIVEIRA, A. D.; de ASSIS, A. L. Dominant height model for site classification of eucalyptus grandis incorporating climatic variables. International Journal of Forestry Research, v. 2013, p. I-7, 2013.

SCOLFORO, H. F; SCOLFORO, J. R. S.; STAPE, J. L.; MCTAGUE, J. P.; BURKHART, H.; MCCARTER, J.; DE CASTRO NETO, F; LOOS, R. A.; SARTORIO, R. C. Incorporating rainfall data to better plan eucalyptus clones deployment in eastern Brazil. Forest Ecology and Management, v. 391, p. 145-153, 2017.

SKOVSGAARD, J. P.; VANCLAY, J. K. Forest site productivity: a review of the evolution of dendrometric concepts for even-aged stands. Forestry, v. 8I, n. I, p. $|3-3|, 2008$.

STATSOFT INC. Sostoft. Available at em: < http:// documentation.statsoft.com/>. Acessed em: I5 jul. 2017.

WALTERS, D. K.; GREGOIRE, T. G.; BURKHART, H. E. Consistent estimation of site index curves fitted to temporary plot data. Biometrics, v. 45, n. I, p. 23-33, 1989. 